\title{
FAKTOR-FAKTOR YANG BERHUBUNGAN DENGAN STATUS GIZI BALITA
}

\author{
Frasiska Trie Septianasari, Taliah, Elvi Destariyani \\ Politeknik Kesehatan Kementerian Kesehatan Bengkulu, Jurusan Kebidanan \\ Jalan Indragiri Nomor 3 Padang Harapan Kota Bengkulu \\ elvi_destariyani@yahoo.com
}

\begin{abstract}
Less of nutrients is one of the nutrient disturbance disease because the less of food concumptions. Children's weights is less to $80 \%$ index of weight accoding to age. Puskesmas Sukamerindu had the highest score of child under five years old with nutrientless. The purpose of this research is to know the relation of mothers knowledge degree economic level and the sun of family members with nutrient degree at Puskesmas Sukamerindu. This research use descriptive analytic research desaign with case control scheme. The population in this research is all of the children under five years old in Puskesmas Sukamerindu region, the sample is 60 childs under five years old with case sample is taking by total sampling and control sample is taking by purposive sampling. The method of taking the data is using secondary data and primary data (quisionary whereas the method of analyzing data is using Chi-Square). The result of univaried analyzing is almost half of part $(31,7 \%)$ mother's had less of knowledge degree, almost half of past $(45,0 \%)$ family had low of economic level, almost half of part $(46,7 \%)$ family had the sum of family members $>4$ persons. The result of bivaried analyzing shows there is a mean relation between mothers knowledge degree $(\mathrm{p}=$ $0,000)$, economic level $(p=0,000)$ with nutriet degree of child under five years old. The result of this research shows there isn't a relation between the sum of family member $(p=0,547)$ with nutrient degree of child under years old. Hoping for the paramedics especially midwife can increasing the nutrient knowledge of the mothers with give a conseling about nutrient and do the monitoring nutrient degree periodicly.
\end{abstract}

Keywords : The number of family members, economic status , nutritional status, level of knowledge of mothers

\begin{abstract}
Abstrak: Gizi kurang merupakan salah satu penyakit gangguan gizi karena kurangnya asupan makan. Puskesmas Sukamerindu memiliki angka tertinggi balita penderita gizi kurang. Tujuan penelitian ini untuk mengetahui faktor-faktor yang berhubungan dengan status gizi di puskesmas sukamerindu. Penelitian ini menggunakan desain deskriptif analitik dengan pendekatan case control. Populasi seluruh balita yang ada di Wilayah Puskesmas Sukamerindu, sampel 60 balita, teknik pengambilan sampel untuk case dengan menggunakan total sampling, sedangkan untuk control menggunakan purposive sampling. Metode pengambilan data menggunakan data sekunder dan data primer, teknik analisis data menggunakan chisquare. Hasil analisis univariat diperoleh hampir sebagian $(31,7 \%)$ ibu dengan pengetahuan yang kurang, hampir sebagian $(45,0 \%)$ keluarga status ekonomi yang rendah, hampir sebagian $(46,7 \%)$ keluarga dengan jumlah anggota keluarga $>4$ orang. Hasil analisis bivariat menunjukkan ada hubungan antara pengetahuan ibu $(\rho=0,000)$ dan status ekonomi $(\rho=0,000)$ dengan status gizi balita. tidak ada jumlah anggota keluarga $(\rho=0,547)$ dengan status gizi balita. Diharapkan bagi petugas kesehatan khususnya bidan agar lebih meningkatkan pengetahuan gizi ibu dengan memberikan penyuluhan tentang gizi dan melakukan pemantauan status gizi secara berkala.
\end{abstract}

Kata kunci : Jumlah anggota keluarga, Status ekonomi, Status gizi balita, Tingkat pengetahuan ibu 
Pembangunan kesehatan diarahkan untuk mempertinggi derajat kesehatan termasuk didalamnya keadaan gizi masyarakat dalam rangka meningkatkan kualitas hidup serta kesejahteraan rakyat pada umumnya (Suhardjo, 2003). Salah satu masalah sosial yang dihadapi Indonesia adalah rendahnya status gizi masyarakat. Hal ini mudah dilihat, misalnya dari berbagai masalah gizi seperti kurang gizi, anemia gizi besi, gangguan akibat kekurangan yodium dan kurang vitamin A (Khomsan, 2002).

Keadaan gizi atau status gizi masyarakat menggambarkan tingkat kesehatan yang diakibatkan oleh keseimbangan antara kebutuhan dan asupan zat-zat gizi yang dikonsumsi seseorang. Anak yang kurang gizi akan menurun daya tahan tubuhnya, sehingga mudah terkena penyakit infeksi. Sebaliknya anak yang menderita penyakit infeksi akan mengalami gangguan nafsu makan dan penyerapan zat-zat gizi sehingga menyebabkan kurang gizi. Anak yang sering terkena infeksi dan gizi kurang akan mengalami gangguan tumbuh kembang yang akan mempengaruhi tingkat kesehatan, kecerdasan dan produktivitas di masa dewasa (Nurlianti,2006).

Status gizi merupakan salah satu determinan utama status kesehatan penduduk. Salah satu indikator status gizi penduduk yang rendah adalah tingginya prevalensi gizi kurang dan gizi buruk pada anak bawah lima tahun (balita) yang didasarkan pada Berat Badan dari umur $(\mathrm{BB} / \mathrm{U})$. Anak balita (1-5 tahun) merupakan kelompok umur yang paling sering menderita akibat kekurangan gizi (KEP) atau termasuk salah satu kelompok masyarakat yang rentan gizi. Gizi kurang atau gizi buruk pada balita dapat berakibat terganggunya pertumbuhan jasmani, terhambatnya partumbuhan dan kecerdasan mereka (Soeditama, 2000).

Masalah gizi dipengaruhi oleh banyak faktor yang saling mempengaruhi secara kompleks. Oleh karena itu, penanganan gizi memerlukan pendekatan yang terpadu, yang mengarah pada pemberdayaan ekonomi keluarga, peningkatan kemampuan dan keterampilan asuhan gizi keluarga serta peningkatan cakupan dan kualitas pelayanan dikarenakan anak mengalami proses pertumbuhan yang sangat pesat, sehingga memerlukan zat-zat makanan yang relatif lebih banyak dengan kualitas yang lebih tinggi, hasil pertumbuhan menjadi dewasa sangat tergantung dari kondisi gizi dan kesehatan sewaktu masa balita (Soeditama, 2000).

Salah satu penyebab gangguan gizi adalah kurangnya pengetahuan gizi atau kemauan untuk menerapkan informasi. Menurut Ursula (2008), Tingkat pengetahuan gizi seseorang berpengaruh terhadap sikap dan perilaku dalam pemilihan makanan yang pada akhirnya berpengaruh pada keadaan gizi individu yang bersangkutan. Semakin tinggi tingkat pengetahuan gizi seseorang diharapkan sema-kin baik pula keadaan gizinya. Ibu yang berpengetahuan gizi baik akan mengupayakan kemampuan menerapkan pengetahuannya di dalam pemilihan dan pengolahan pangan sehingga konsumsi makanan mencukupi kebutuhan lebih terjamin (Ursula, 2008). Menurut penelitian Santi, dkk (2012), pengetahuan ibu tentang kesehatan dan masalah gizi berperan nyata dalam resiko gizi kurang.

Masalah gizi juga dipengaruhi oleh status ekonomi, Menurut Sajogyo dalam Ursula (2008), faktor sosial ekonomi mempunyai peranan besar dalam masalah gizi dan kebiasaan makan masyarakat. Ketersediaan pangan suatu keluarga sangat dipengaruhi oleh tingkat pendapatan keluarga tersebut. Rendahnya status ekonomi merupakan rintangan yang menyebabkan orang tidak mampu membeli, memilih pangan yang bermutu gizi baik dan beragam. Teori ini sesuai dengan hasil penelitian Anindita (2010), dari hasil penelitian menunjukkan bahwa keadaan ekonomi keluarga mempengaruhi status gizi dan kecukupan protein dan zinc pada balita.

Jumlah anggota keluarga dalam satu keluarga juga mempengaruhi status gizi, jumlah anggota keluarga yang melebihi anjuran yaitu 3 anak saja dalam satu keluarga ditambah dengan status ekonomi yang sudah rendah maka akan menimbulkan kekurangan pangan dalam keluarga tersebut sehingga berpengaruh terhadap status gizi balita 
(Soeditama, 2000). Teori ini sejalan dengan penelitian Saba'atmaja (2010) yang menunjukkan ada hubungan yang bermakna antara status gizi kurang dengan jumlah anak dalam keluarga.

Penelitian ini secara umum bertujuan untuk mengetahui adanya hubungan tingkat pengetahuan ibu, status ekonomi, dan jumlah anggota keluarga dengan status gizi balita di wilayah puskesmas sukamerindu kota bengkulu tahun 2013.

\section{BAHAN DAN CARA KERJA}

Jenis penelitian ini adalah analitik dengan desain Study case control. Tempat penelitian dilaksanakan di wilayah Puskesmas Sukamerindu Kota Bengkulu dalam kurun waktu yaitu tanggal 10 juni sampai 5 juli 2013. Populasi dalam penelitian ini adalah semua balita yang berkunjung ke Puskesmas dan posyandu Sukamerindu tahun 2012 bulan januari sampai desember sejumlah 1480 balita, dengan 30 balita gizi bermasalah (24 balita gizi kurang dan 6 balita gizi buruk). Besar sampel adalah 60 Balita. Sampel kasus diambil secara total sampling sejumlah 30 balita yang dengan gizi bermasalah umur 0-60 bulan. Sampel control berbanding 1:1 dengan sampel kasus yaitu balita dengan gizi tidak bermasalah umur 0-60 bulan sebanyak 30 balita yang diambil secara Purposive Sampling yaitu suatu pengambilan sampel yang didasarkan pada suatu pertimbangan tertentu yang dibuat oleh peneliti. Metode pengambilan data menggunakan data sekunder dan data primer, teknik analisis data menggunakan chisquare.

\section{HASIL}

\section{Analisis univariat}

Berdasarkan Tabel 1 menunjukkan dari 60 responden yang memiliki balita hampir sebagian $(31,7 \%)$ responden dengan pengetahuan yang kurang tentang gizi, sebagian besar $(55 \%)$ responden memiliki status ekonomi yang tinggi, sebagian besar $(53,3 \%)$ responden memiliki jumlah anggota keluarga $<4$ orang, dan hampir sebagian (40\%) responden menderita gizi kurang.
Tabel 1 Gambaran pengetahuan ibu, jumlah anggota keluarga dan status gizi balita

\begin{tabular}{|c|c|c|c|c|c|}
\hline \multirow[b]{2}{*}{ Variabel } & \multicolumn{3}{|c|}{ Status Gizi } & \multirow{2}{*}{$\begin{array}{l}\text { Frekuensi } \\
\quad(\mathrm{n}=60)\end{array}$} & \multirow{2}{*}{$\begin{array}{c}\text { Presentase } \\
(100 \%)\end{array}$} \\
\hline & $\overline{\text { Buruk }}$ & Kurang & $\begin{array}{c}\text { Norma } \\
1\end{array}$ & & \\
\hline \multicolumn{6}{|l|}{ Pengetahuan } \\
\hline Kurang & 5 & 12 & 2 & 19 & 31,7 \\
\hline Cukup & 1 & 9 & 7 & 17 & 28,3 \\
\hline Baik & 0 & 3 & 21 & 24 & 40,0 \\
\hline \multicolumn{6}{|l|}{$\begin{array}{l}\text { Status } \\
\text { ekonomi }\end{array}$} \\
\hline Rendah & 6 & 17 & 4 & 27 & 45 \\
\hline Tinggi & 0 & 7 & 26 & 33 & 55 \\
\hline \multicolumn{6}{|l|}{$\begin{array}{l}\text { Jumlah } \\
\text { keluarga }\end{array}$} \\
\hline$>4$ orang & 4 & 10 & 14 & 28 & 46,7 \\
\hline$\leq 4$ orang & 2 & 14 & 16 & 32 & 53,3 \\
\hline
\end{tabular}

\section{Analisis bivariat}

Berdasarkan Tabel 2 diketahui bahwa dari 6 respoden penderita gizi buruk, sebagian besar $(83,3 \%)$ responden memiliki ibu dengan pengetahuan kurang, sebagian kecil $(16,7 \%)$ responden memiliki ibu dengan pengetahuan cukup, dan tidak satupun (0\%) responden yang memiliki ibu dengan pengetahuan baik. Kemudian dari 24 responden balita gizi kurang sebagian besar $(50,0 \%)$ memiliki ibu yang berpengetahuan kurang, hampir sebagian $(37,5 \%)$ balita gizi kurang yang memiliki ibu dengan pengetahuan cukup, dan sebagian kecil $(12,5 \%)$ yang memiliki ibu dengan pengetahuan yang baik.

Tabel 3 Analisis Factor-Faktor Yang Berhubungan Dengan Status Gizi Balita

\begin{tabular}{|c|c|c|c|c|c|c|c|}
\hline \multirow{3}{*}{ Variabel } & \multicolumn{6}{|c|}{ Status Gizi } & \multirow{3}{*}{$P$} \\
\hline & \multicolumn{2}{|c|}{ Buruk } & \multicolumn{2}{|c|}{ Kurang } & \multicolumn{2}{|c|}{ Normal } & \\
\hline & $\mathrm{n}$ & $\%$ & $\mathrm{n}$ & $\%$ & $\mathrm{n}$ & $\%$ & \\
\hline \multicolumn{8}{|l|}{ Pengetahuan } \\
\hline Kurang & 5 & 26 & 1 & 63,2 & 2 & 1 & 0,00 \\
\hline Cukup & 1 & 5,9 & 9 & 52,9 & 7 & 41,2 & \\
\hline Baik & 0 & 0 & 3 & 12,5 & 21 & 87,5 & \\
\hline Total & 6 & 100 & 24 & 100 & 30 & 100 & \\
\hline \multicolumn{8}{|l|}{$\begin{array}{l}\text { Status } \\
\text { ekonomi }\end{array}$} \\
\hline Rendah & 6 & 100 & 17 & 70,8 & 4 & 13,3 & 0,000 \\
\hline Tinggi & 0 & 0 & 7 & 29,2 & 26 & 86,7 & \\
\hline Total & 6 & 10 & 24 & 100 & 30 & 100 & \\
\hline \multicolumn{8}{|l|}{$\begin{array}{l}\text { Jml Anggota } \\
\text { Klg }\end{array}$} \\
\hline$>4$ orang & 4 & 66,7 & 10 & 41,7 & 14 & 46,7 & 0,547 \\
\hline$\leq 4$ orang & 2 & 33,3 & 14 & 58,3 & 16 & 53,3 & \\
\hline Total & 6 & 100 & 24 & 100 & 30 & 100 & \\
\hline
\end{tabular}

Berdasarkan hasil uji statistik diperoleh nilai $\mathrm{p}=0,000(\leq 0,05)$ hal ini berarti me- 
nunjukkan bahwa ada hubungan antara pengetahuan gizi ibu dengan status gizi balita.

Dari 6 responden balita gizi buruk, seluruh (100\%) responden memiliki keluarga dengan status ekonomi rendah, dan tidak satupun $(0 \%)$ responden memiliki keluarga dengan status ekonomi tinggi. Kemudian dari 24 responden, sebagian besar $(70,8 \%)$ balita gizi kurang memiliki keluarga dengan status ekonomi rendah, dan hampir sebagian $(29,2 \%)$ balita gizi kurang memiliki keluarga dengan status ekonomi tinggi. Berdasarkan hasil uji statistik diperoleh nilai $p=0,000$ ( $\leq$ $0,05)$ hal ini berarti menunjukan bahwa ada hubungan antara status ekonomi dengan status gizi balita.

Berdasarkan tabel 2 terlihat dari 6 responden balita gizi buruk, sebagian besar $(66,7 \%)$ memiliki keluarga yang jumlah anggota keluarganya orang $>4$ orang, dan hampir sebagian $(33,3 \%)$ responden memiliki keluarga yang jumlah anggota keluarganya $\leq 4$ orang. Kemudian, hampir sebagian $(41,7 \%)$ balita gizi kurang yang memiliki keluarga dengan jumlah anggota keluarga $>4$ orang, dan sebagian besar $(58,3 \%)$ balita gizi kurang yang memiliki jumlah anggota keluarga $\leq 4$ orang. Berdasarkan hasil uji statistik diperoleh nilai $p=0,457(\leq 0,05)$ hal ini berarti tidak ada hubungan antara jumlah anggota keluarga dengan status gizi balita.

\section{PEMBAHASAN}

\section{Hubungan pengetahuan dan status gizi balita}

Berdasarkan hasil penelitian menunjukkan dari 60 responden, hampir sebagian $(31,7 \%)$ dengan pengetahuan yang kurang tentang gizi seperti tidak mengetahui bagaimana status gizi yang baik, membuat menu makanan secara bervariasi, dan mengolah makanan dengan baik. Berdasarkan hasil analisis bivariat didapatkan hasil dari 6 responden balita gizi buruk, hampir seluruh $(83,3 \%)$ responden memiliki ibu dengan tingkat pengetahuan yang kurang. Dari hasil penelitian diketahui bahwa masih banyak balita dengan gizi buruk dan kurang yang memiliki ibu dengan pengetahuan kurang. Hasil penelitian ini sejalan dengan teori Khomsan (2002) yang menyatakan bahwa pengetahuan gizi adalah apa yang diketahui oleh seseorang tentang suatu hal tentang gizi yang secara formal maupun informal, dan segala sesuatu yang diketahui seorang ibu tentang sikap dan perilaku seseorang dalam memilih makanan, serta pengetahuan dalam mengolah makanan dan menyiapkan makanan. Tingkat pengetahuan seseorang berpengaruh terhadap sikap dan perilaku dalam pemilihan makanan yang pada akhirnya akan berpengaruh pada keadaan gizi individu. Berdasarkan penelitian Khotimah (2012), dari hasil analisa statistik dengan menggunakan uji chi-square, didapatkan nilai $\mathrm{p}=0,000 \quad(\mathrm{p}<$ $\alpha 0,05)$, dapat disimpulkan bahwa ada hubungan yang sangat bermakna antara tingkat pengetahuan gizi ibu dengan status gizi balita. Hasil penelitian ini sesuai dengan hasil penelitian Lutviana (2010) yang menyatakan ada hubungan yang bermakna antara pengetahuan gizi dengan status gizi anak dimana dari 22 balita, terdapat 15 balita gizi kurang yang memiliki ibu dengan tingkat pengetahuan yang kurang.

Berdasarkan hasil penelitian menunjukkan bahwa sebagian kecil $(6,7 \%)$ responden dengan gizi normal juga memiliki ibu dengan tingkat pengetahuan yang rendah, dalam penelitian didapatkan bahwa dengan tingkat pengetahuan ibu yang kurang ternyata masih ada balita yang status gizinya normal, menurut asumsi peneliti hal ini dikarenakan bukan hanya tingkat pengetahuan ibu yang mempengaruhi status gizi balita, karena tingkat pengetahuan merupakan salah satu penyebab tidak langsung kejadian kurang gizi, banyak faktor lain yang mempengeruhi status gizi seperti konsumsi makanan dan riwayat penyakit dari balita itu sendiri. Hal ini sesuai dengan teori Purba (2005) bahwa timbulnya gizi kurang juga dapat disebabkan oleh faktor lain yaitu ketahanan pangan keluarga yang tidak memadai, asupan makanan yang kurang, dan riwayat penyakit.

Berdasarkan hasil uji statistik diperoleh ada hubungan antara pengetahuan ibu dengan status gizi balita. Hasil penelitian ini sesuai dengan teori Soedioetama (2000) bahwa semakin tinggi pengetahuan ibu tentang gizi dan kesehatan maka penilaian terhadap 
makanan semakin baik, artinya penilaian terhadap makanan tidak fokus terhadap rasa saja, tetapi juga memperhatikan hal-hal yang lebih luas.

\section{Hubungan Status ekonomi dan status gizi balita}

Berdasarkan hasil penelitian menunjukkan dari 60 responden balita, hampir sebagian (45\%) responden memiliki keluarga dengan tingkat pendapatan yang rendah, hal ini dapat menyebabkan kemampuan untuk membeli bahan pangan kurang dan dikhawatirkan akan berpengaruh terhadap status gizi balita, karena berdasarkan hasil analisis hubungan antara status ekonomi dengan status gizi balita diketahui bahwa dari 6 responden balita gizi buruk, seluruh responden $(100 \%)$ memiliki keluarga dengan status ekonomi rendah, dan tidak satupun $(0 \%)$ responden gizi buruk yang memiliki keluarga dengan status ekonomi tinggi. Kemudian dari 24 reponden balita gizi kurang, sebagian besar $(70,8 \%)$ responden memiliki keluarga dengan status ekonomi yang rendah, dan sebagian $(29,2 \%)$ responden memiliki keluarga dengan status ekonomi yang tinggi.

Berdasarkan hasil uji statistik diperoleh ada hubungan antara status ekonomi dengan status gizi balita. Hasil penelitian ini sesuai dengan teori Supariasa (2002) yang menyatakan bahwa pendapatan keluarga akan mempengaruhi pola makan, dimana proporsi anak yang mengalami gizi kurang berbanding terbalik dengan pendapatan keluarga. Semakin kecil pendapatan penduduk semakin tinggi prosentase anak yang kekurangan gizi. Menurut Suranadi (2008) pendapatan merupakan hal utama yang berpengaruh terhadap kualitas menu, pendapatan yang rendah menyebabkan daya beli yang rendah pula, sehingga tidak mampu membeli pangan dalam jumlah yang diperlukan, keadaan ini berbahaya untuk kesehatan keluarga dan akhirnya dapat berakibat buruk terhadap status gizi terutama bayi dan balita.

Berdasarkan penelitian yang dilakukan Lutviana (2010) menyebutkan ada hubungan antara tingkat pendapatan dengan status gizi balita. Penyebab utama gizi kurang pada anak balita adalah rendahnya penghasilan keluarga.
Hasil penelitian menunjukkan dari 30 responden balita gizi normal, sebagian kecil $(13,3 \%)$ responden memiliki keluarga dengan status ekonomi yang rendah. Keluarga dengan status ekonomi yang rendah ternyata memiliki balita dengan gizi normal, menurut asumsi peneliti hal ini dapat disebabkan ternyata dengan status ekonomi yang rendah, keluarga tersebut masih mampu membeli bahan pangan yang bergizi walaupun bahan pangan tersebut tidak memiliki nilai harga yang tinggi, dan keluarga disini walaupun dengan tingkat ekonomi yang rendah, mereka bisa memanfaat kan pekarangan untuk menanam sayuran sendiri dan tidak perlu membeli diluar, atau pun dengan cara memvariasikan makanan serta pemilihan makanan yang kreatif, contoh dengan satu butir telur saja dapat memenuhi kebutuhan protein satu anak dan harga dari telur tersebut juga terjangkau sehingga tidak usah membeli daging yang harganya tidak terjangkau oleh keluarga tersebut. Kemudian dari 30 responden balita gizi normal hampir sebagian $(86,7 \%)$ responden memiliki keluarga dengan status ekonomi yang tinggi, dari hasil penelitian ini menurut asumsi peneliti dapat dikatakan bahwa status ekonomi yang tinggi dapat mempengaruhi status gizi balita karena dengan status ekonomi yang tinggi dipastikan bahwa keluarga tersebut dapat membeli bahan pangan dan dapat mencukupi asupan gizi semua anggota keluarganya.

Hasil penelitian ini sesuai dengan teori Suranadi (2008) menyatakan bahwa apabila penghasilan keluarga meningkat, penyediaan lauk pauk akan meningkat mutunya. Pada umunya jika pendapatan naik jumlah dan jenis makanan cenderung juga membaik. Pendapatan keluarga sangat mempengaruhi terhadap konsumsi makanan sehari-hari. Apabila pendapatan rendah maka makanan yang dikonsumsi tidak mempertimbangkan nilai gizi, tetapi nilai materi lebih menjadi pertimbangan.

\section{Hubungan jumlah anggota keluarga dan status gizi balita}

Hasil penelitian menunjukkan dari 60 responden yang memiliki balita, hampir sebagian $(46,7 \%)$ responden memiliki keluarga dengan jumlah anggota keluarga $>4$ orang, 
sebagian besar $(53,3 \%)$ responden memiliki jumlah anggota keluarga $\leq 4$ orang. Dapat diketahui bahwa di Wilayah Puskesmas Sukamerindu masih terdapat warga yang memiliki keluarga dengan jumlah anggota keluarga $>4$ orang.

Berdasarkan analisis hubungan antara jumlah anggota keluarga dengan status gizi balita dari 6 reponden balita gizi buruk, sebagian besar $(66,7 \%)$ responden memiliki keluarga yang jumlah anggota keluarganya $>4$ orang, dan hampir sebagian $(33,3 \%)$ respon-den memiliki keluarga yang jumlah anggota keluarganya $\leq 4$ orang. Kemudian, dari 24 responden balita gizi kurang hampir sebagian $(41,7 \%)$ responden memiliki keluarga dengan jumlah anggota keluarga $>4$ orang, dan sebagian besar $(58,3 \%)$ responden. yang memiliki jumlah anggota keluarga $\leq 4$ orang. Berdasarkan hasil penelitian, diketahui bahwa dari beberapa responden balita dengan gizi buruk dan kurang memiliki keluarga dengan jumlah anggota keluarga $>4$ orang. Menurut asumsi peneliti hal ini dikarenakan apabila anggota keluarga >4 orang, maka pengaturan dalam pemberian makan akan tidak merata dan ketersediaan pangan dan pengaturan pangan akan sulit dijangkau.

Hasil penelitian ini sesuai dengan teori Suharmi dalam Ruhana (2008) bahwa jumlah anggota keluarga akan mempengaruhi terhadap tingkat konsumsi pangan, jumlah anggota keluarga yang besar akan diikuti dengan distribusi pangan yang tidak merata sehingga menyebabkan anak dalam keluarga kekurangan gizi. Jumlah anggota keluarga dapat mempengaruhi status gizi dari individu anak karena meningkatnya persaingan untuk sumberdaya rumah tangga yang terbatas, terutama yang berhubungan dengan makanan dan keterbatasan waktu dan energi yang dimiliki ibu untuk merawat setiap anggota rumah tangga tersebut.

Berdasarkan hasil analisis juga didapatkan hasil dari 30 responden balita gizi normal hampir sebagian (46,7\%) responden memiliki jumlah anggota keluarga $>4$ orang, dan sebagian besar $(53,3 \%)$ responden memiliki jumlah anggota keluarga $\leq 4$ orang. Hal ini diperkuat dengan hasil uji statistik yaitu nilai $\mathrm{p}=0,295(>0,05)$.

Hasil penelitian ini sejalan dengan hasi penelitian Lutviana (2010) yang menunjukkan tidak ada hubungan antara jumlah anggota keluarga dengan status gizi balita (nilai $\mathrm{p}=0,768$ ). Terdapat 12 balita gizi kurang dari 30 keluarga, dan terdapat 10 balita gizi kurang dari 20 keluarga tidak catur warga $(>=4)$. Pada umumnya kasus kurang gizi sering ditemukan pada keluarga besar dibandingkan dengan keluarga kecil, sehingga anak-anak yang dihasilkan dari keluarga demikian lebih cenderung kurang gizi. Karena selain keluarga kecil kesejahteraannya lebih terjamin maka kebutuhan pangan juga akan terpenuhi dengan baik jika dibandingkan dengan keluarga besar.

Menurut Berg dalam Suranadi (2008) yang mengatakan bahwa jumlah anggota keluarga yang ada di dalam suatu keluarga secara langsung akan mempengaruhi status gizi anggota keluarga yang ada, hal ini ditentukan terkait dengan ketersediaan pangan yang ada di dalam keluarga. Bertambahnya jumlah anggota keluarga, maka pengaturan pengeluaran pangan sehari-hari semakin sulit. Hal ini mengakibatkan kualitas dan kuantitas pangan yang diperoleh semakin tidak mencukupi anggota keluarga termasuk anak balita.

Namun, besar keluarga merupakan salah satu faktor secara tidak langsung yang mempengaruhi terjadinya kurang gizi sehingga meskipun jumlah anggota keluarga di dalam suatu keluarga besar namun apabila ibu selaku orang yang mengasuh dan yang mengkoordinir pemberian makan dalam pemenuhan konsumsi keluarganya berlaku seimbang maka tidak akan terjadinya gangguan gizi.

\section{KESIMPULAN}

Disimpulkan bahwa terdapat hubungan tingkat pengetahuan ibu dengan status gizi balita di wilayah Puskesmas Sukamerindu Bengkulu tahun 2013, terdapat hubungan status ekonomi dengan status gizi balita di wilayah Puskesmas Sukamerindu Bengkulu tahun 2013 dan tidak ada hubungan jumlah anggota keluarga dengan status gizi balita di wilayah Puskesmas Sukamerindu Bengkulu 
tahun 2013, artinya jumlah anggota keluarga tidak terbukti dapat mempengarui status gizi balita. Hasil penelitian ini hendaknya dapat ditindak lanjuti oleh pihak puskesmas untuk dapat melakukan deteksi dini perkembangan balita dan selalu memantau status gizi setiap

\section{DAFTAR RUJUKAN}

Adiningsih, S. 2010. Waspadai Gizi Balita Anda. Jakarta : PT. Elex Media Komputindo.

Almatsier, S. 2005. Prinsip dasar ilmu gizi. Jakarta : PT. Gramedia Pustaka Utama.

Anindita, P. 2012. Hubungan Tingkat Pendidikan Ibu, Pendapatan Keluarga, Kecukupan Protein dan Zinc Dengan Stunting (Pendek) Pada Balita Usia 6-36 Bulan diKecamatan Tembalang Kota Semarang. Jurnal Kesehatan Masyarakat Vol.2, No.1. Diakses tanggal 20 april 2013 dari http://ejournals1.undip.ac.id/index.php/jkm

Arisman.2004. Buku Ajar Ilmu Gizi Dalam Daur Kehidupan. Jakarta: Buku Kedokteran EGC.

Badan Penelitian dan Pengembangan Kesehatan Depkes RI, 2009. Riset Kesehatan Dasar (Riskesdas) 2010. Badan Penelitian dan Pengembangan Kesehatan Departemen Kesehatan RI. Jakarta.

Baliwati, dkk. 2004. Neraca Bahan Makanan. Diktat Jurusan Gizi Masyarakatdan Sumberdaya Keluarga. Fakultas Pertanian. Institut Pertanian Bogor.

Departemen Kesehatan Republik Indonesia.2008. Tabel Baku Rujukan WHO/NHCS tentang penelitian Status Gizi Anak Perempuan dan Anak Laki-laki usia 0-59bulan Menurut Berat Badan dan Umur $(B B / U)$. Direktorat Bina Gizi.

Dinas Kesehatan Provinsi Bengkulu, 2010. Profil Kesehatan Provinsi Bengkulu Tahun 2010.Dinkes Kota Bengkulu. 2011. Profil Kesehatan Provinsi Bengkulu

Gibson R,S. 2005. Principle of Nutritional Assesement : Antropometric Assesment to Body Size. Second Edition. New York. Oxford University.

Hidayat, A. 2012. Metode Penelitian Kebidanan dan Teknik Analisis Data. Jakarta:Salemba Medika.

Khotimah, dkk. 2012. Hubungan Pengetahuan gizi Ibu dan Pola Makan Balita dengan Status Gizi Balita (12-59 bulan) diWilayah Kerja Puskesmas Gandus Kecamatan Gandus, Palembang. Jurnal Pembangunan Manusia Vol.6 No.2.

Khomsan. 2002. Pangan dan Gizi untuk Kesehatan. Jakarta: PT Rajagrafindo Persada.

Marimbi, H.2010. Tumbuh Kembang, Status Gizi, dan Imunisasi Dasar Pada Balita. Yogyakarta : Muhamedika.

Moehji, S.2003.Ilmu Gizi II. Peranan Gizi dalam Berbagai Kurun Usia dalam Daur Kehidupan. Jakarta : Papas Sinar Sinanti.

Proverawati, A.2011. Ilmu Gizi untuk Keperawatan dan Gizi Kesehatan. Muhamedika :Yogyakarta. balita di wilayah kerjanya serta memberikan konseling dan penkes tentang gizi terutama cara memvariasi kan menu dan cara mengolah makanan yang baik, serta kebutuhan gizi balita, dan perkembangan pada balita.

Purba , RB. 2005. Buku Ajar Program Implementasi dan Evaluasi Program Gizi Jilid I.Program Perbaikan Gizi Makro Departemen Kesehatan R.I. Manado.

Ruhana, C. Hubungan Pola Asuh Anak dengan status gizi balita umur 24-59 Bulan di wilayah Terkena Tsunami Kabupaten Pidie Propinsi Nanggroe aceh Darusalam Tahun 2008. Tesis. Medan : Universitas Sumatra Utara

Saba'atmaja. 2010. Analisis Determinan Positive Deviance Status Gizi Balita diWilayah Miskin dengan Prevalensi Kurang Gizi Rendah dan Tinggi. Jurnal Gizi dan Pangan VOL.5, NO.2.

Santi, dkk. 2012. Hubungan Antara Kondisi Sosial Ekonomi dan Higinie Sanitasi Lingkungan dengan Status Gizi Anak Usia 2-5 Tahun diKecamatan Seginim Kabupaten Bengkulu Selatan Tahun 2012. Jurnal Penelitian Pengelolaan Sumberdaya Alam dan Lingkungan. Diakses tanggal 20 april 2013.

Sediaoetama, AD. 2000. Ilmu gizi untuk mahasiswa dan profesi jilid 1. Jakarta : PT Dian Rakyat.

Sudiharto. 2007. Asuhan Keperawatan Keluarga dengan Pendekatan Keperawatan Transkultural. Jakarta: EGC.

Supariasa, I. dkk. 2002. Penilaian Status Gizi. Jakarta : Buku Kedokteran ECG.

Suranadi. dkk. 2008. Karakteristik Keluarga dan Pola Asuh Pada Balita Gizi Kurang dan Gizi Buruk diKabupaten Lombok barat. Jurnal Kesehatan Prima Vol .2, NO. 2.

Susanti, S. 2010. Pengaruh Penyuluhan Gizi terhadap Perilaku Ibu dalam Penyediaan Menu Seimbang untuk Balita di Desa Ramunia-I Kecamatan Pantai Labu Kabupaten Deli Serdang Tahun 2010. Jurnal Skripsi Fakultas Kesehatan Mayarakat Universitas Sumatera Utara. Diakses tanggal 23 April 2013.

Syukriawati, R. 2011. Faktor-faktor Yang Berhubungan Dengan Status Gizi Kurang Pada Anak Usia 2459 Bulan diKelurahan Pamulang Barat Kota Tangerang Selatan Tahun. Jurnal Skripsi Fakultas Kesehatan Masyarakat. Universitas Islam Negeri Syarif Hidayatullah Jakarta. Diakses tanggal 18 April 2013.

. Hubungan Perilaku Ibu dalam Pemberian Gizi Seimbang dengan Status Gizi pada Balita di Posyandu Kelurahan Depok Kecamatan Pancoran Mas Kota Depok Tahun 2010. Jurnal Universitas Pembangunan Nasional Veteran. Diakses tanggal 18 April 2013. 
Ursula, D 2008. Studi Tentang Aspek Sosial Ekonomi dan Budaya Serta Kaitannya Dengan Masalah Gizi Kurang diKabupaten Manggarai, Nusa
Tenggara Timur . Jurnal Bogor Agricultural University. Diakses tanggal 2 April 2013 